\title{
PENGARUH VARIASI KONSENTRASI EKSTRAK DAUN TEH (Camellia sinensis L) TERHADAP SIFAT FISIK DEODORANT STICK
}

\author{
Agung Nur Cahyanta ${ }^{1}$, Endang Istriningsih ${ }^{2}$, Dinar Anggia Zen ${ }^{3}$, Tomy Sugiarto Gautama ${ }^{4}$ \\ 1,2,3 Program Studi S1 Farmasi Sekolah Tinggi Ilmu Kesehatan Bhakti Mandala Husada Slawi, Jl. Cut Nyak \\ Dhien No.16 Kalisapu, Slawi, Kabupaten Tegal Telp/Fax (0283) 6197570 \\ Hp : +62 8222131571, Email : aku.cahyanta@gmail.com
}

\begin{abstract}
Abstrak
Rasa percaya diri seseorang akan meningkat bila badannya berbau harum dan segar. Kebersihan dan bau badan merupakan hal penting dalam higienitas dan penampilan seseorang. Bau badan sangat berhubungan dengan sekresi keringat seseorang dan adanya pertumbuhan mikroorganisme. Deodorant stick merupakan kosmetika yang diformulasikan khusus untuk mengatasi bau badan, yang berfungsi untuk mengurangi keringat karena mengandung zat astringen dan antimikroba yang berguna mencegah pertumbuhan mikroba pada keringat. Salah satu tanaman yang berkhasiat obat dikenal dan digunakan oleh masyarakat ialah tanaman Teh (Camellia sinensis L) yang mengandung Tanin. Menurut Hara (1993) mengemukakan bahwa tanin dapat dipakai sebagai antimikroba, juga berkhasiat sebagai astringen. Ekstrak adalah suatu produk hasil pengambilan zat aktif dari tanaman menggunakan pelarut yang sesuai, kemudian pelarutnya diuapkan kembali sehingga zat aktif ekstrak menjadi pekat. Sifat fisik dan karekteristik deodorant stick sangat dipengaruhi oleh komposisi penyusunnya, faktor formulasi sangat berpengaruh terhadap kualitas deodorant yang dihasilkan, salah satu penyusun dalam formulasi deodoran stick adalah ekstrak daun Teh sebagai zat aktif. Variasi konsentrasi ekstrak daun Teh 5\% (formula X1), 10\% (formula X2) dan 15\% (formula X3) berpengaruh terhadap sifat fisik deodorant stick yang dihasilkan, pada uji organoleptis diperoleh warna dan kepadatan yang berbeda untuk tiap formula. Analisis data uji waktu leleh menggunakan One Way ANOVA diperoleh nilai signifikan 0,019<0,05, dapat disimpulkan bahwa pada taraf kepercayaan 95\% menunjukkan ada pengaruh yang nyata perbedaan konsentasi ekstrak daun Teh terhadap waktu leleh deodorant stick, dengan waktu leleh tercepat pada formula X1 sebesar 64,66 menit. Pada analisis data uji titik lebur menggunakan One Way ANOVA diperoleh nilai signifikan 0,019<0,05 dapat disimpulkan bahwa pada taraf kepercayaan $95 \%$, ada pengaruh yang nyata perbedaan konsentrasi ekstrak daun Teh terhadap titik lebur deodorant stick, dengan titik leleh terendah adalah pada formula X1 dengan suhu $44^{\circ} \mathrm{C}$. Pengujian keamanan deodorant stick dengan uji iritasi akut dermal diperoleh bahwa pada ketiga formula nilai indeks iritasi menunjukkan kriteria iritan sangat ringan (rentang $0,0-0,4$ ).
\end{abstract}

\section{Kata Kunci : Daun Teh, Deodorant, Variasi, Konsentrasi.}

\begin{abstract}
Someone's confidence will increase if his/her body is fragrant and fresh. Cleanliness and body odor are important things in hygiene and someone's performance. The body odor is related to sweat secretion and the existence of microorganism growth. Deodorant stick is a special formulated cosmetic to overcome the body odor which has a function to reduce sweat because it contains astringent substance and antimicrobial used to prevent the microbial growth in sweat. One of the medicinal plants and used by many people is tea plant (Camellia sinensis L) containing tannin. According to Hara (1993), tannin can be applied as antimicrobial and has astringent. Extract was a product which took from the result of active substances of the plant using the appropriate solvent then the solvent was re-evaporated so that the active substances of the extract became concentrated. Physical properties and characteristics of deodorant stick were very influenced by the composition; formulation factors were also related to the quality of resulted deodorant; one of the constituent of deodorant stick formulation was tea leaf extract as active substance. Variations in concentration of tea leaf extract were 5\% (formulation X1), 10\% (formulation X2) and 15\% (formulation $\mathrm{X} 3$ ); those were influenced in physical properties of resulted deodorant stick. Based on the organoleptic test, it was obtained that there was a difference color and density on each formulation. The analysis of melting point test used One Way ANOVA which had significance level of $0.019<0.05$; it means that on 95\% level of trust showed that there was a real effect of different concentration of tea leaf extract on melting point of
\end{abstract}


deodorant stick; the fastest melting point was on formulation X1 namely 64.66 minutes. The analysis of absolute zero using One Way ANOVA was obtained that significance level of $0.019<0.05$; it was concluded that $95 \%$ level of trust, there was a significant effect on the different concentration of tea leaf extract against absolute zero of deodorant stick; the lowest absolute zero was on formulation X1 with a temperature of $44^{\circ} \mathrm{C}$. The irritation test of deodorant stick showed that irritation index value on the third formulation was in very mild criteria (range of $0.0-0.4$ ).

\section{Keywords: Tea Leaf, Deodorant, Variation,Concentration}

\section{A. Pendahuluan}

Kebersihan dan bau badan merupakan hal utama dan penting dalam higienitas dan penampilan. Seseorang akan mempunyai kepercayaan diri yang lebih tinggi bila badannya berbau harum dan menyegarkan ${ }^{[1]}$.

Bau badan sangat berhubungan dengan sekresi keringat seseorang dan adanya pertumbuhan mikroorganisme, serta adanya pengaruh dari makanan dan bumbu-bumbuan yang berbau khas seperti bawang-bawangan. Keringat merupakan hasil sekresi dari kelenjar-kelenjar yang bermuara pada kulit dan merupakan sebum (zat berminyak yang diproduksi secara alami oleh tubuh), asam lemak tinggi, dan debris (pigmen yang terkumpul sisa hasil metabolisme pada kulit), maka keringat dapat membantu terbentuknya produk berbau hasil dekomposisi (penguraian) oleh bakteri. Bau badan lebih tercium pada daerah dengan kelenjar apokrin lebih banyak, seperti pada ketiak (aksila) dan daerah pubik ${ }^{[2]}$.

Masalah bau badan dapat diatasi dengan menjaga kebersihan tubuh secara teratur dan pemakaian sediaan topikal khusus seperti antirespiran dan deodorant. Antirespiran dan deodorant mengandung suatu antiseptik yang berfungsi untuk menahan atau mengurangi dekomposisi bakteri sehingga dapat mengontrol bau badan ${ }^{[3]}$. Salah satu tanaman yang berkhasiat obat dikenal dan digunakan oleh masyarakat ialah tanaman Teh (Camellia sinensis L), flavonoid dan tanin yang ada dalam daun Teh berfungsi sebagai penangkal radikal bebas. Tanin juga berkhasiat sebagai astringen yang dapat menciutkan selaput lendir ${ }^{[4]}$.

Ekstrak adalah sediaan pekat yang diperoleh dengan mengekstrasi zat aktif dari simplisia nabati atau hewani mengunakan pelarut yang sesuai, kemudian semua atau hampir semua pelarut diuapkan dan massa atau serbuk yang tersisa diperlakukan sedemikian hingga memenuhi baku yang telah ditetapkan ${ }^{[5]}$.

Ekstrak yang berasal dari tumbuhan dapat dikelompokan atas dasar sifatnya, Ekstrak Encer (Extractum tenue), Ekstrak Kental (Ectractum spissum), Ekstrak Kering (Extractum siccum), Ekstrak Cair (Extractum fluidum), diartikan sebagai ekstrak cair yang dibuat sedemikian rupa sehingga satu bagian simplisia sesuai dengan dua bagian (kadangkadang juga satu bagian) ekstrak cair. ${ }^{[6]}$.

BHAMADA, JITK, Vol. 10, No. 1, April 2019 
Sifat fisik dan karekteristik deodorant stick sangat dipengaruhi oleh komposisi penyusunnya, sehingga faktor formulasi sangat berpengaruh terhadap kualitas deodorant yang dihasilkan, salah satu komponen penyusun dalam formulasi deodorant stick adalah ekstrak daun Teh sebagai zat aktif. Jumlah ekstrak daun Teh yang terkandung dalam setiap formula akan berpengaruh terhadap sifat fisik deodorant stick yang dihasilkan melalui pengamatan uji mutu fisik meliputi organoleptik, homogenitas, $\mathrm{pH}$, dan titik lebur.

Selanjutnya semua hasil sediaan deodorant stick dilakukan uji kemanan dengan uji iritasi akut dermal secara in vivo.

\section{B. Metode Penelitian}

Jenis penelitian yang digunakan adalah penelitian eksperimental dengan rancangan penelitian Post Test Control Group Design Only. Penelitian ini dimulai dengan determinasi tanaman, pengumpulan dan pengolahan daun Teh, pembuatan ekstrak daun Teh, uji kandungan kimia, formulasi deodorant stick, dan uji sifat fisik deodorant stick yang dihasilkan, analisis data menggunakan One Way ANOVA, dilanjutkan dengan uji keamanan.

\section{Alat dan Bahan}

Bahan yang digunakan dalam penelitian ini daun Teh yang diperoleh dari kecamatan Bumijawa, kabupaten Tegal, Cera alba, Oleum kakao, minyak kelapa, Stearyl alkohol, minyak jeruk, minyak lavender, mentholum, propylenglikol, propyl paraben, minyak jarak. Alat yang digunakan dalam penelitian ini adalah alat-alat gelas, oven drying, moisture analyzer, mechanical stirrer, rotary evaporator, timbangan analitik, waterbath, termometer, stamper dan mortir,.

\section{Cara Kerja}

Tanaman Teh dilakukan determinasi dengan melihat ciri-ciri tanaman yang diperoleh dari daerah Bumijawa, Kabupaten Tegal, Jawa Tengah. Hasil determinasi sesuai dengan kunci determinasi Steenis, Tjitrosoepomo.

Daun Teh (Camellia sinensis L) yang masih segar, dan cukup tua disortasi terlebih dahulu. Dilakukan pencucian dengan air mengalir hingga bersih ditiriskan kemudian dikeringkan dengan menggunakan oven drying pada suhu kurang dari $60^{\circ} \mathrm{C}$ selama 8 jam. Simplisia kemudian digiling dan diayak dengan pengayak mesh 60 menjadi serbuk dengan ukuran yang homogen ${ }^{[7]}$. Serbuk simplisia diuji kadar air dengan moisture analyzer, ditimbang berat serbuk keringnya dan disimpan dalam wadah tertutup baik terlindung cahaya matahari.

Pembuatan ekstrak dengan metode maserasi menggunakan penyari etanol $70 \%$. Sebanyak 700 g serbuk daun Teh dimaserasi dua kali masing-masing $350 \mathrm{~g}$ serbuk dengan menggunakan etanol 70\% sebanyak $2.625 \mathrm{ml}$, diaduk dengan alat Mechanical stirrer selama 3 jam dengan kecepatan 400 rpm, didiamkan 
selama 5 hari. Kemudian dilakukan penyaringan dengan kertas saring, filtrat yang diperoleh dicampur dan dipekatkan dengan rotary evaporator suhu $60^{\circ} \mathrm{C}$ dengan kecepatan $50 \mathrm{rpm}$.

Ekstrak yang dihasilkan dihitung rendemennya, kemudian dilakukan uji fitokimia untuk mengetahui kandungan ekstrak daun Teh meliputi :

a. Uji flavonoid

Ditimbang 0,5 gram ekstrak ditambahkan 2 mg serbuk Mg, lalu ditambahkan 3 tetes $\mathrm{HCl}$ pekat. Apabila terbentuk warna orange, merah atau kuning menunjukkan adanya flavonoid [8].

b. Uji alkaloid

Sejumlah $1 \mathrm{~mL}$ ekstrak ditambah 1,5 mL HCl 2\%, dipanaskan di atas penangas air kemudian disaring. Filtrat yang diperoleh dibagi 2. Filtrat pertama ditambahkan 2 tetes pereaksi Meyer, filtrat kedua ditambahkan 2 tetes pereaksi Dragendrof. Adanya senyawa alkaloid ditunjukkan oleh endapan putih dengan pereaksi Meyer dan endapan jingga dengan pereaksi Dragendorf pada masingmasing ${ }^{[9]}$.

\section{c. Uji saponin}

Sejumlah $1 \mathrm{~mL}$ ekstrak dimasukkan ke dalam tabung reaksi dan ditambah $3 \mathrm{~mL}$ akuades, dikocok selama 15 menit untuk diamati, jika terjadi busa setinggi $1 \mathrm{~cm}$ yang bertahan selama 15 menit maka menunjukkan adanya saponin [9].

d. Uji tanin
Sejumlah $1 \mathrm{~mL}$ ekstrak ditambah $2 \mathrm{~mL}$ akuades dan 2 tetes $\mathrm{FeCl} 3$ dan jika terjadi warna biru tua atau coklat tua menunjukkan adanya tanin ${ }^{[9]}$.

e. Uji antrakuinon

Uji Brontrager dilakukan dengan cara melarutkan $2 \mathrm{ml}$ sampel dengan $10 \mathrm{ml}$ akuades kemudian disaring, filtrat diekstrak dengan $5 \mathrm{ml}$ benzena. Hasil ekstrak dibagi menjadi 2 bagian, $A$ dan $B$. Filrat A digunakan sebagai blangko dan filtrat $\mathrm{B}$ ditambahkan $5 \mathrm{ml}$ ammonia kemudian dikocok, bila terdapat warna merah berarti hasil positif ${ }^{[10]}$.

Hasil ekstrak di formulasi menjadi sediaan deodorant stik dengan formulasi seperti pada tabel.

Tabel 1. Formula Salep Uji

\begin{tabular}{llccc}
\hline & & \multicolumn{3}{c}{ Formula (\%) } \\
\hline No. & Nama Bahan & FI & F II & F III \\
\hline 1. & Ekstrak daun Teh & 5 & 10 & 15 \\
2. & Cera alba & 3 & 3 & 3 \\
3. & Basis & 15 & 15 & 15 \\
4. & Minyak kelapa & 10 & 10 & 10 \\
5. & Stearyl alkohol & 20 & 20 & 20 \\
6. & Minyak jeruk & 5 & 5 & 5 \\
7. & Minyak lavender & 5 & 5 & 5 \\
8. & Mentholum & 0,4 & 0,4 & 0,4 \\
9. & Propylenglikol & 15 & 15 & 15 \\
10. & Propyl paraben & 0,02 & 0,02 & 0,02 \\
11. & Minyak jarak & 21,58 & 16,58 & 11,58 \\
\hline
\end{tabular}

Deodorant stick dibuat sebanyak tiga formula dengan basis yang sama, dengan konsentrasi ekstrak daun Teh yang berbeda yaitu $5 \%$, $10 \%$, dan $15 \%$, setiap formula dibuat sebanyak 40 gram. 
Pembuatan dengan melebur cera alba, basis dan stearyl alkohol diatas waterbath, selanjutnya semua bahan ditambahkan diaduk sampai homogen, diamkan selama 10 menit agar suhu tidak terlalu panas, kemudian menambahkan menthol dan minyak jeruk diaduk sampai homogen selanjutnya memasukan dalam cetakan, diamkan sampai memadat, disimpan pada suhu $25^{\circ} \mathrm{C}$.

Hasil deodorant stik diuji mutu fisik meliputi :

\section{a. Uji organoleptis}

Pemeriksaan meliputi bentuk, warna, aroma dan tekstur.

b. Uji homogenitas

Pengujian homogenitas dilakukan dengan melihat sediaan secara kasat mata, apakah sediaan deodorant stick masih terdapat partikel kasar atau tidak, jika tidak maka dikatakan sudah homogen.

c. Uji pH

Penentuan $\mathrm{pH}$ deodoran stik dapat menggunakan kertas $\mathrm{pH}$. Ukuran $\mathrm{pH}$ untuk batasan kulit adalah 4,5-7 [11].

d. Uji Waktu Meleleh

Uji dilakukan dengan 5 gram deodorant stick dimasukkan dalam air dengan suhu $37^{\circ} \mathrm{C}$, kemudian dicatat waktu sampai deodorant meleleh.

e. Uji titik lebur

Deodorant stick dipotong setengah memanjang dengan berat yang sama setiap formula, dimasukkan ke dalam beaker glass dan dipanaskan diatas waterbath, suhu berlahan-lahan dinaikkan, kemudian diamati pada suhu berapa deodorant melebur.

Selain uji mutu fisik, sediaan juga dilakukan uji keamanan dengan uji iritasi akut dermal prosedur uji berdasarkan Peraturan Kepala BPOM N0.7 Th. 2014, Tentang Pedoman Uji Toksisitas Nonklinik secara In Vivo ${ }^{[12]}$, yang di modifikasi pengujian triplo pada satu kelinci.

\section{Hasil dan Pembahasan}

Hasil determinasi tanaman menunjukkan bahwa daun yang digunakan berasal dari tanaman spesies Camellia sinensis (L), Familia Theaceae, dengan morfologi daun seperti pada tabel dan gambar berikut.

\section{Tabel 2. Morfologi daun Teh}

\begin{tabular}{clc}
\hline No. & \multicolumn{1}{c}{ Spesifikasi } & Keterangan \\
\hline 1. & Warna & Hijau \\
2. & Permukaan & Kaku, licin \\
3. & Bentuk & Eliptis memanjang \\
4. & Ujung daun & Runcing \\
5. & Pangkal daun & Runcing \\
6. & Tepi daun & Bergerigi \\
7. & Jumlah helai daun & Tunggal \\
\hline
\end{tabular}

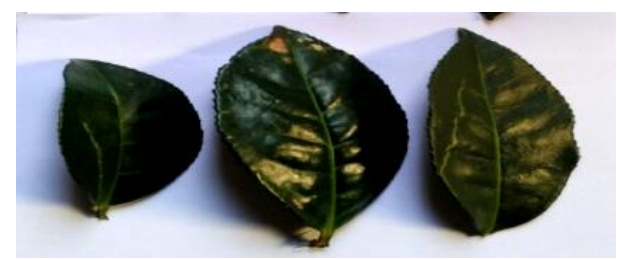

Gambar 1. Daun Teh

Daun Teh segar dikeringkan dan diperoleh simplisia daun Teh dengan kadar air $8,78 \%$. Pengeringan ini bertujuan untuk mengurangi kadar air dalam bahan hingga kurang dari $10 \%$ untuk mencegah kerusakan 
akibat adanya pertumbuhan mikroorganisme baik dalam pengolahan maupun penyimpanan [13].

Simplisia kering diserbuk untuk memperluas permukaan yang kontak dengan pelarut dan memecah sel sehingga proses ekstraksi akan lebih maksimal, serbuk simplisia diekstraksi dengan etanol $70 \%$, ekstrak yang dihasilkan adalah ekstrak kental warna hijau pekat, seberat $123,8 \mathrm{~g}$ dengan rendemen $17,68 \%$. Penggunaan etanol $70 \%$ dalam ekstraksi karena memiliki kemampuan untuk melarutkan senyawa polar dan semi polar yang sesuai dengan sifat kandungan zat aktif pada daun Teh. Pemilihan metode maserasi karena maserasi tanpa melalui proses pemanasan sehingga tidak merusak kandungan zat aktif dalam daun Teh.

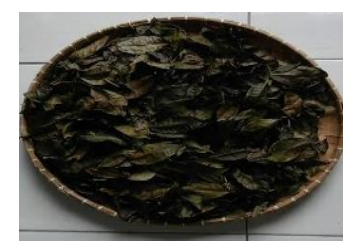

a

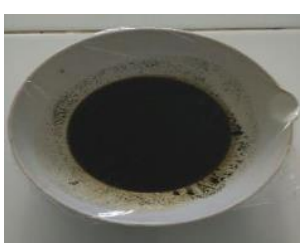

$\mathrm{b}$
Gambar 2. a. Simplisia; b. Ekstrak daun Teh

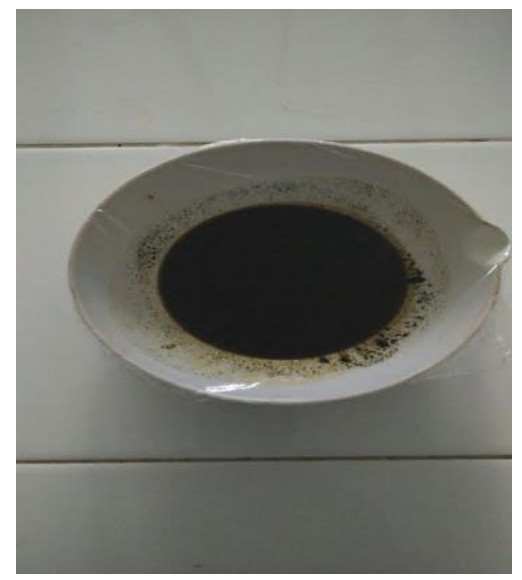

Pembuatan deodorant stick menggunakan metode peleburan karena terdapat bahan yang berbentuk padat sehingga harus dileburkan untuk dapat bercampur dengan bahan yang lain, selain itu metode peleburan juga mempermudah dalam proses pencetakan.

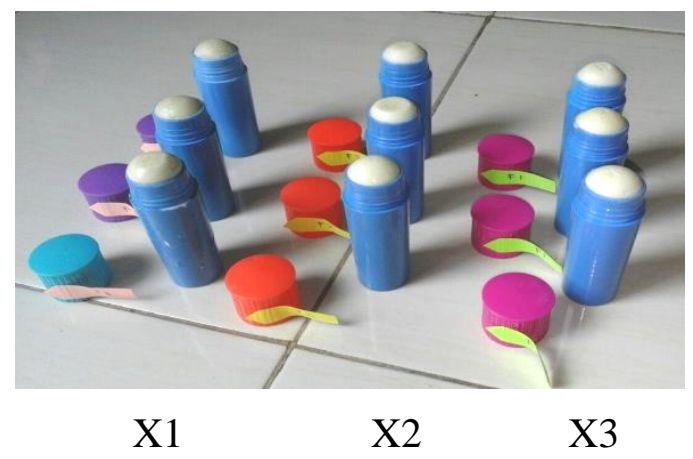

Gambar 3. Hasil deodoran stik ekstrak daun Teh

Keterangan :

X1 : Deodorant stick ekstrak daun Teh 5\% X2 : Deodorant stick ekstrak daun Teh $10 \%$ X3 : Deodorant stick ekstrak daun Teh 15\%

Uji organoleptis untuk mengamati bentuk, bau dan warna dari sediaan deodoran stik yang telah dibuat, hasil yang diperoleh pada tabel berikut :

\section{Tabel 3. Hasil pengamatan organoleptis}

\begin{tabular}{ccccc}
\hline \multirow{2}{*}{ Formula } & \multicolumn{4}{c}{ Organoleptis } \\
\cline { 2 - 5 } X1 & Warna & Bentuk & Bau & Tekstur \\
X2 & $\begin{array}{c}\text { Padat } \\
*\end{array}$ & Harum & Halus \\
X2 & Putih & $\begin{array}{c}\text { Padat } \\
* *\end{array}$ & Harum & Halus \\
X3 & $\begin{array}{c}\text { Putih } \\
\text { kekuningan }\end{array}$ & $\begin{array}{c}\text { Padat } \\
* * *\end{array}$ & Harum & Halus \\
\hline
\end{tabular}

Keterangan :

* : Tingkat kepadatan

Warna yang dihasilkan dari ketiga formula deodorant stick memiliki perbedaan, pada formula X1 dan X2 memiliki warna 
putih yang terlihat hampir sama, sedangkan pada formula X3 dihasilkan warna yang lebih gelap. Penggunaan ekstrak daun Teh pada konsentrasi $15 \%$ pada formula X3 mampu mempengaruhi warna sediaan deodoran stik, dari putih menjadi lebih gelap.

Urutan konsistensi kepadatan yang diperoleh $\mathrm{X}_{1}<\mathrm{X}_{2}<\mathrm{X}_{3}$, ini bermakna semakin tinggi konsentrasi ekstrak daun Teh dalam formula deodorant stick, semakin padat deodoran stik yang dihasilkan, hal ini disebabkan karena konsentrasi ekstrak daun Teh yang kental sehingga semakin banyak mengandung ekstrak akan cenderung lebih meningkat kepadatannya.

Pengujian $\mathrm{pH}$ dilakukan untuk mengetahui apakah deodorant stick yang dihasilkan dari ketiga formula bersifat asam, basa atau netral. Pengukuran $\mathrm{pH}$ dilakukan dengan menggunakan stik $\mathrm{pH}$ dan indikator $\mathrm{pH}$.

Tabel 4. Hasil pengamatan $\mathrm{pH}$

\begin{tabular}{cccc}
\hline \multirow{2}{*}{ Formula } & \multicolumn{3}{c}{$\mathrm{pH}$ Replikasi } \\
\cline { 2 - 4 } & $\mathrm{I}$ & $\mathrm{II}$ & $\mathrm{III}$ \\
\hline $\mathrm{X} 1$ & 7 & 7 & 7 \\
$\mathrm{X} 2$ & 7 & 7 & 7 \\
$\mathrm{X} 3$ & 7 & 7 & 7 \\
\hline
\end{tabular}

Hasil uji pH dari ketiga formula yang menggunakan konsentrasi ekstrak daun Teh berbeda, diperoleh hasil $\mathrm{pH}$ yang sama yaitu 7, ini menunjukkan bahwa konsentrasi ekstrak daun Teh pada range 5-15\% tidak berpengaruh terhadap perubahan $\mathrm{pH}$ sediaan. Hasil pH 7 masih sesui dengan persyaratan
pH untuk sediaan kosmetik yaitu berkisar antara 4,5-7,0.

Uji homogenitas bertujuan untuk mengetahui apakah bahan-bahan yang digunakan tercampur secara merata dan tidak mengandung partikel-partikel padat. Deodorant stick yang baik harus memiliki sifat yang ideal, massa yang baik dan tidak mengandung partikel kasar, sehingga ketika dioleskan pada kulit terasa lembut.

Berdasarkan pengamatan yang dilakukan pada irisan deodorant stick yang dihasilkan, terlihat sediaan menunjukan hasil homogen sesuai dengan syarat pada Farmakope Indonesia edisi ketiga, ini menggambarkan pencampuran tiap bahan pada masing-masing formula telah merata sehingga deodorant stick homogen dan bebas partikel kasar.

Hasil uji homogenitas menunjukkan variasi konsentrasi ekstrak daun teh 5\%, 10 $\%$ dan $15 \%$ pada deodoran stik, tidak berpengaruh pada homogenitas.

Tabel 5. Hasil pengamatan homogenitas

\begin{tabular}{ccc}
\hline \multirow{2}{*}{ Formula } & \multicolumn{2}{c}{ Pengamatan } \\
\cline { 3 - 3 } X1 & Gambar & Deskripsi \\
\hline X2 & Homogen \\
& & Homogen \\
X3 & & Homogen \\
\hline
\end{tabular}

Uji waktu leleh bertujuan untuk mengetahui berapa lama waktu yang 
dibutuhkan oleh deodorant stick meleleh pada suhu $37^{\circ} \mathrm{C}$ sesuai dengan suhu tubuh, hal ini penting karena berkaitan dengan absorbsi zat aktif ke dalam kulit dan durasi kerja deodorant stick yang dihasilkan.

Hasil uji statistik one way anova taraf kepercayaan 95\% dengan nilai signifikansi $\alpha$ $=5 \%$, diperoleh nilai signifikansi sebesar $0,019<0,05$ maka Ha diterima Ho ditolak, sehingga dapat disimpulkan bahwa ada pengaruh yang nyata, perbedaan konsentasi ekstrak daun Teh terhadap waktu leleh deodorant stick.

Tabel 6. Hasil pengamatan uji waktu leleh

\begin{tabular}{ccccc}
\hline \multirow{2}{*}{ Formula } & \multicolumn{3}{c}{ Replikasi (menit) } & Rata-Rata \\
\cline { 2 - 4 } & I & II & III & (menit) \\
\hline X1 & 64 & 65 & 65 & 64,6 \\
X2 & 67 & 67 & 64 & 66,0 \\
X3 & 68 & 66 & 67 & 67,0 \\
K+ & 63 & 64 & 64 & 63,6 \\
\hline
\end{tabular}

Keterangan :

$\mathrm{K}+$ : Deodorant stick di pasaran

Waktu leleh yang paling cepat adalah formula X1, sehingga deodoran akan lebih cepat diserap oleh kulit dibandingkan dengan formula yang lain. Selain itu formula X1 ekstrak daun Teh 5\% juga memiliki rata-rata waktu leleh yang paling dekat dengan formula $\mathrm{K}+$ deodorant stick di pasaran.

Uji titik lebur bertujuan untuk mengetahui suhu maksimal deodorant stick dapat melebur, sehingga dapat diketahui apakah ada pengaruh variasi konsentrasi ekstrak daun Teh terhadap titik lebur deodoran yang dihasilkan. Titik lebur juga bermanfaat untuk memberikan gambaran suhu maksimal saat penyimpanan.

Hasil uji titik lebur menunjukan hasil yang berbeda untuk tiap formula karena semakin tinggi konsentrasi ekstrak daun Teh semakin tinggi suhu titik leburnya, seperti terlihat pada tabel berikut.

\section{Tabel 7. Hasil pengamatan uji titik lebur}

\begin{tabular}{ccccc}
\hline \multirow{2}{*}{ Formula } & \multicolumn{3}{c}{ Replikasi $\left({ }^{\circ} \mathrm{C}\right)$} & Rata-Rata \\
\cline { 2 - 4 } & I & II & III & $\left({ }^{\circ} \mathrm{C}\right)$ \\
\hline X1 & 44 & 44 & 44 & 44,0 \\
X2 & 47 & 47 & 47 & 47,0 \\
X3 & 53 & 53 & 53 & 53,0 \\
K+ & 43 & 43 & 43 & 63,6 \\
\hline
\end{tabular}

Untuk melihat apakah ada pengaruh konsentrasi ekstrak daun Teh terhadap titik lebur deodorant stick dilakukan uji statistik dengan one way anova menggunakan tingkat kepercayaan 95\% dan signifikansi ( $\alpha=5 \%$ ) diperoleh signifikansi $0,030<0,05$ maka Ha diterima Ho ditolak. Sehingga dapat disimpulkan bahwa ada pengaruh yang nyata variasi konsentasi ekstrak daun Teh terhadap titik lebur deodoran stik. Hasil uji titik lebur juga menunjukkan bahwa formula X1 ekstrak daun Teh 5\% memiliki titik lebur yang paling dekat dengan Formula K+ deodorant stick di pasaran.

Iritasi merupakan gejala inflamasi yang terjadi pada kulit atau membrane mukosa segera setelah perlakuan, berkepanjangan atau berulang ketika menggunakan bahan kimia atau bahan lain. Terjadinya iritasi disebabkan oleh suatu bahan dapat terjadi pada setiap 
orang, tidak melibatkan sistem imun tubuh dan ada beberapa faktor-faktor yang memegang peranan seperti keadaan permukaan kulit, lamanya bahan bersentuhan dengan kulit dan konsentrasi dari bahan. Berdasarkan hal tersebut, maka harus dilakukan uji iritasi, adanya tanda-tanda iritasi berupa eritema dan udema pada kulit hewan coba, maka ada kemungkinan terjadi iritasi pada kulit manusia.

Iritasi yang muncul pada kulit kelinci ditandai dengan adanya eritema dan udema pada pengamatan ke 1, 24, 48 dan 72 jam kontak dengan deodorant stick, sebagai blanko digunakan aquadest steril.

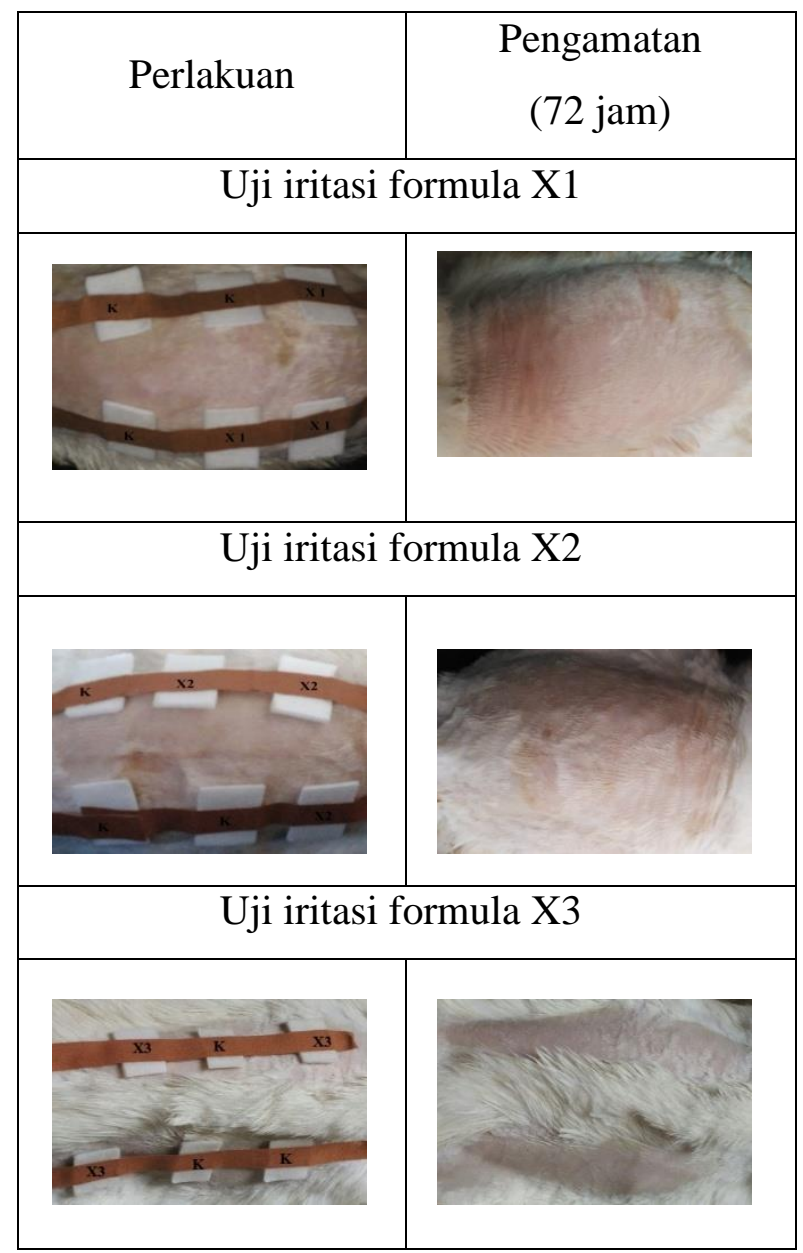

Gambar 4. Hasil uji iritasi setiap formula
Hasil pengamatan uji iritasi formula X1, X2 dan X3 tidak menunjukkan adanya eritema dan udema pada kulit kelinci.

\section{Tabel 8. Hasil Perhitungan indeks iritasi}

\begin{tabular}{clc}
\hline No. & \multicolumn{1}{c}{$\begin{array}{c}\text { Kelompok } \\
\text { uji }\end{array}$} & $\begin{array}{c}\text { Indeks } \\
\text { Iritasi }\end{array}$ \\
\hline 1. & Kontrol Negatif (aqudest) & 0,0 \\
2. & Formula X1 & 0,0 \\
3. & Formula X2 & 0,0 \\
3. & Formula X3 & 0,0 \\
\hline
\end{tabular}

Penghitungan indeks iritasi menunjukkan nilai 0,0 dengan kriteria iritasi iritan sangat ringan (rentang 0,0-0,4). Bahan-bahan dalam formulasi dan ekstrak daun Teh 5\%,10\% dan $15 \%$ serta campuran dari semua bahan tersebut tidak menimbulkan iritasi pada kulit kelinci, sehingga ketiga formula aman untuk digunakan.

\section{Simpulan}

Terdapat pengaruh konsentrasi ekstrak daun Teh terhadap sifat fisik deodorant stick berdasarkan pada uji titik lebur dan waktu leleh. Dari hasil penelitian diperoleh formula yang paling baik bila dibandingkan dengan kontrol positif adalah formula X1. Variasi konsentrasi ekstrak daun Teh (5\%, 10\%, $15 \%$ ) tidak menimbulkan iritasi pada uji keamanan deodorant stick.

\section{E. Ucapan Terima Kasih}

Terima kasih kami sampaikan kepada STIKes Bhamada yang telah memberikan dukungan pendanaan. 


\section{F. Daftar Pustaka}

1. Hasby, E. (2001). Keringat dan Bau Badan. www.kompas.com. 28 April 2008.

2. Anonis, P.D., 1976. Perfume, Deodoran Antiperspirant, Drug and Cosmetic Industry. Hal 119.

3. Musfiroh, I., dan Sriwidodo. 2008. Uji Aktivitas dan Stabilitas Deodoran Bentuk Batang (stick) Dengan Zat Aktif Minyak Atsiri Daun Nilam (Pogostemon Cablin Blanco Benth), Laporan Penelitian, Fakultas Farmasi Universitas Padjadjaran.

4. Santoso F, 2016. Kajian Perilaku Konsumen Mahasiswa dan Kinerja Atribut Produk Minuman "Milk Tea Maica", Skripsi, Fakultas Pertanian Universitas Lampung, Lampung : Hal. 7.

5. Departemen Kesehatan RI. 1995. Farmakope Indonesia Edisi IV, Jakarta: Depkes RI.

6. Voight, R. 1994. Buku Pelajaran Teknologi Farmasi, diterjemahkan oleh Noerono Soendani. Yogyakarta : Gadjah Mada Universitas Press. Hal 579.

7. Cahyanta, A. N. 2016. Penetapan Kadar Flavonoid Total Ekstrak Daun Pare Metode Kompleks Kolorimetri dengan Pengukuran Absorbansi secara Spektrofotometri. Jurnal Ilmiah Farmasi. 5 (1): 58-6.

8. Harborne, J.B. 1987. Metode Fitokimia Penuntun Cara Modern Menganalisis. Tumbuhan. Penerbit ITB. Bandung.

9. Anonim,(1989), Materia Medika Indonesia, Jilid V, Direktorat Jenderal. Pengawasan Obat dan Makanan (Dirjen POM), Departemen Kesehatan Republik Indonesia.
10. Marliana SD, Venty S, Suyono, 2005. Skrining Fitokimia dan Analisis Kromatografi Lapis Tipis Komponen Kimia Buah Labu Siam (Sechium edule Jacq. Swartz.) dalam Ekstrak Etanol, Jurnal Biofarmasi 3 (1), Jurusan Biologi FMIPA UNS, Hal.26-31.

11. Wasitaatmadja, S.M., 1997, Penuntun Ilmu Kosmetik Medik, 3, 4, 11-15, 23, 117-120, Universitas Indonesia Press, Jakarta.

12. Anonim. 2014. Peraturan Kepala BPOM N0.7 Th. 2014, Tentang Pedoman Uji Toksisitas Nonklinik secara In Vivo.

13. Anonim. 2011. Pedoman Teknologi Penanganan Pascapanen Tanaman Obat. Kementrian Pertanian. Jakarta. 